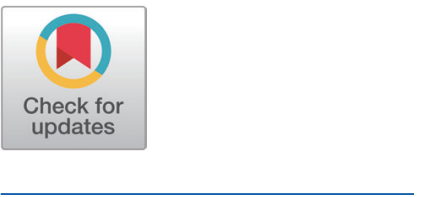

Received: May 27, 2021

Revised: Jul 9, 2021

Accepted: Jul 21, 2021

\#These authors contributed equally to this work.

${ }^{*}$ Corresponding author Mee-Ryung Lee

Department of Food and Nutrition,

Daegu University, Gyeongsan 38453 ,

Korea.

Tel: +82-53-850-6837

E-mail:mrlee@daegu.ac.kr

Won-Jae Lee

Department of Animal Bioscience (Institute of Agriculture and Life Science), Gyeongsang Nationa University, Jinju 52828, Korea.

Tel: +82-55-772-1884

E-mail: wjleewisc@gnu.ac.kr

Copyright $\odot 2021$ Korean Society of Animal Sciences and Technology.

This is an Open Access article distributed under the terms of the Creative Commons Attribution Non-Commercial License (http:// creativecommons.org/licenses/bync/4.0/) which permits unrestricted non-commercial use, distribution, and reproduction in any medium, provided the original work is properly cited.

ORCID

Ho-Kyung $\mathrm{Ha}$

https://orcid.org/0000-0002-0773-6585

\section{Development and evaluation of probiotic delivery systems using the rennet-induced gelation of milk proteins}

\author{
Ho-Kyung Ha ${ }^{1,2 \#}$, Ji-Young Hong ${ }^{3 \#}$, Istifiani Lola Ayu ${ }^{4}$, Mee-Ryung Lee ${ }^{4 \star}$ and \\ Won-Jae Lee ${ }^{3 *}$ \\ ${ }^{1}$ Department of Animal Science and Technology, Sunchon National University, Sunchon 57922, Korea \\ ${ }^{2}$ Interdisciplinary Program in IT-Bio Convergence System, Sunchon National University, Sunchon \\ 57922, Korea \\ ${ }^{3}$ Department of Animal Bioscience (Institute of Agriculture and Life Science), Gyeongsang National \\ University, Jinju 52828, Korea \\ ${ }^{4}$ Department of Food and Nutrition, Daegu University, Gyeongsan 38453, Korea
}

Abstract

The aims of this study were to develop a milk protein-based probiotic delivery system using a modified rennet-induced gelation method and to determine how the skim milk powder concentration level and $\mathrm{pH}$, which can affect the rennet-induced intra- and inter-molecular association of milk proteins, affect the physicochemical properties of the probiotic delivery systems, such as the particle size, size distribution, encapsulation efficiency, and viability of probiotics in simulated gastrointestinal tract. To prepare a milk protein-based delivery system, skim milk powder was used as a source of milk proteins with various concentration levels from 3 to $10 \%(\mathrm{w} / \mathrm{w})$ and rennet was added to skim milk solutions followed by adjustment of $\mathrm{pH}$ from 5.4 or 6.2. Lactobacillus rhamnosus GG was used as a probiotic culture. In confocal laser scanning microscopic images, globular particles with a size ranging from $10 \mu \mathrm{m}$ to 20 $\mu \mathrm{m}$ were observed, indicating that milk protein-based probiotic delivery systems were successfully created. When the skim milk powder concentration was increased from 3 to $10 \%$ $(\mathrm{w} / \mathrm{w})$, the size of the delivery system was significantly $(p<0.05)$ increased from 27.5 to 44.4 $\mu \mathrm{m}$, while a significant $(p<0.05)$ increase in size from 26.3 to $34.5 \mu \mathrm{m}$ was observed as the $\mathrm{pH}$ was increased from 5.4 to 6.4. An increase in skim milk powder concentration level and a decrease in $\mathrm{pH}$ led to a significant $(p<0.05)$ increase in the encapsulation efficiency of probiotics. The viability of probiotics in a simulated stomach condition was increased when probiotics were encapsulated in milk protein-based delivery systems. An increase in the skim milk powder concentration and a decrease in $\mathrm{pH}$ resulted in an increase in the viability of probiotics in simulated stomach conditions. It was concluded that the protein content by modulating skim milk powder concentration level and $\mathrm{pH}$ were the key manufacturing variables affecting the physicochemical properties of milk protein-based probiotic delivery systems.

Keywords: Milk protein, Probiotics, Delivery system, Rennet 
Ji-Yung Hong

https://orcid.org/0000-0002-9380-2824

Istifiani Lola Ayu

https://orcid.org/0000-0001-7459-3935

Mee-Ryung Lee

https://orcid.org/0000-0003-4688-7316

Won-Jae Lee

https://orcid.org/0000-0001-8391-6863

Competing interests

No potential conflict of interest relevant to

this article was reported.

Funding sources

This work was supported by Basic Science

Research Program (NRF-2017R1D1A1B

03033260 and NRF-2017R1D1A1B

03032731) through the National Research

Foundation of Korea (NRF) funded by the

Ministry of Education.

Acknowledgements

Not applicable.

Availability of data and material Upon reasonable request, the datasets of this study can be available from the corresponding author.

\section{Authors' contributions}

Conceptualization: Lee MR, Lee WJ.

Data curation: Ha HK, Hong JY.

Formal analysis: Ha HK, Hong JY.

Methodology: Ha HK, Hong JY, Ayu IL.

Software: Ha HK, Hong JY.

Validation: Ha HK, Hong JY, Ayu IL.

Investigation: Lee MR, Lee WJ.

Writing - original draft: Ha HK, Hong JY.

Writing - review \& editing: Lee MR, Lee WJ.

Ethics approval and consent to participate This article does not require IRB/IACUC approval because there are no human and animal participants.

\section{INTRODUCTION}

Probiotics can be defined as "live microorganisms which, when administered in adequate numbers, confer a health benefit on the host"[1]. Owing to the beneficial effects of probiotics, such as reduction in the incidence and duration of childhood diarrhea, improvement in symptoms of the irritable bowel syndrome, and regulation of intestinal immunity, demands for probiotic-formulated food products are increasing across the world [2,3]. Probiotics have been incorporated in various foods including dairy products (e.g., yogurt, cheese, and ice cream) and non-dairy products (e.g., chocolate, cereals, and juices) and global probiotic market is expected to reach US $\$ 46.55$ billion by 2020 [4-6]. However, there remain problems on the viability of probiotics when probiotics have been used in foods [4]. To provide their beneficial effects on the host, it is necessary that probiotics survive through the upper gastrointestinal tracts and sufficient numbers of probiotics reach the intestine alive [7]. To reach a sufficient number of viable probiotics to the intestinal epithelium, probiotic foods should contain at least $10^{6}-10^{7} \mathrm{CFU} / \mathrm{g}$ at the time of consumption [8-10]. However, the number of viable cell in the intestinal epithelium is often low because the number of probiotic can be easily decreased under adverse and harsh conditions during food processing (e.g., heat treatment), storage, and digestion (e.g., acidic $\mathrm{pH}$ of stomach) [11]. Therefore, it is important to protect probiotics and keep them alive until reaching the intestine.

Microencapsulation technologies, such as spray-drying, spray-congealing, extrusion, and coacervation, have been used for the protection and delivery of probiotics $[4,12,13]$. Spray drying is regarded as a low cost process since it is suitable for high-volume production and requires low energy input., Therefore, spray drying has been widely used to encapsulate probiotics in various matrixes and to produce microparticles delivering probiotics [4]. However, high heat temperature (e.g., > $130^{\circ} \mathrm{C}$ ) during spray drying negatively affected the viability of encapsulated probiotics $[11,14,15]$. Moreover, non-dairy origin delivery materials, such as alginate, gellan-gum, and xanthan, cannot be applied to dairy foods in some countries $[11,16]$. Therefore, it is necessary to produce an effective delivery system for probiotics using dairy origin delivery materials, such as milk proteins with mild heat treatment.

Rennet is an enzymatic mixture with a protease activity. Chymosin, the major component of rennet, can hydrolyze peptide bond between phenylalanine (residue 105) and methionine (residue106) in $\kappa$-casein [17]. The cleavage of $\kappa$-casein on the surface of casein micelles results in a decrease in the net negative charge and an increase in their hydrophobicity, which leads to aggregation of casein micelles and forms a gel [11]. Heidebach et al. [11] produced dairy-based probiotic delivery system using the emulsification and rennet-induced gelation of skim milk. This method is relatively simple and suitable for both lab-scale and high volume manufacturing since specialist equipments are not necessary to use. However, in the study of Heidebach et al. [11], very high concentration level $(35 \%, \mathrm{w} / \mathrm{w})$ of skim milk powder was used for the encapsulation of probiotics, which can increase the production cost and lead to form larger particles $(\sim 69 \mu \mathrm{m})$. Although an increase in the size of delivery system could increase the encapsulation efficiency and viability of probiotics in previous studies [18,19], larger delivery system may negatively affect the textural and sensorial properties of foods $[4,18]$. Compared with spray drying method performed at high temperature above $>100^{\circ} \mathrm{C}$, sub-ambient temperature treatment between $5^{\circ} \mathrm{C}$ and $25^{\circ} \mathrm{C}$ was used in rennet-induced gelation method, which could make it advantageous to minimize heatinduced damage for probiotics [20]. Moreover, milk proteins have lower viscosity than highly viscous non-dairy delivery materials including alginate, gellan-gum, and xanthan. Because of high viscosity of those non-dairy delivery materials even at low concentration, the developing nondairy based gel networks can have the low density, which cannot offer efficient protection for 
encapsulated materials [11]. Therefore, rennet-induced gelation of milk proteins can be used as an ideal method for the encapsulation of probiotics.

To produce cost-effective probiotic delivery systems, the concentration level of skim milk powder should be reduced (e.g., below 10\%). Moreover, to understand how the manufacturing processes can modulate the physicochemical characteristics of probiotic delivery systems including size and zeta potential, it is necessary to study the relationships between the manufacturing variables and physicochemical properties of probiotic delivery systems. In this study, we hypothesized that the manufacturing variables, such as milk protein concentration level and $\mathrm{pH}$, that affect the rennetinduced gelation, may play important roles on the physicochemical properties of probiotic delivery systems, the encapsulation efficiency of probiotics, and viability of probiotics during gastrointestinal digestion.

The objectives of this study were to produce probiotic delivery system using rennet-induced gelation of milk proteins and to study how manufacturing variables, such as skim milk powder concentration level and $\mathrm{pH}$, affect the physicochemical properties of probiotic delivery systems and the viability of encapsulated probiotics during in vitro gastrointestinal digestion.

\section{MATERIALS AND METHODS}

\section{Chemicals and reagents}

Skim milk powder with protein content of 35\% (w/w) and rennet (Natural standard plus 290) were purchased from Maeil Dairies (Seoul, Korea) and Chr. Hansen pty. (Bayswater, Melbourne, Australia), respectively. $\mathrm{CaCl}_{2}$, Tween 80 , Span $80, \mathrm{NaCl}, \mathrm{KCl}, \mathrm{NaHCO}_{3}$, pepsin from porcine gastric mucosa, bile extract porcine, and acridine orange were purchased from Sigma-Aldrich (St. Louis, MO, USA).

\section{Microbial culture}

Probiotic strain, Lactobacillus rhamnosus GG, was cultured in de Man, Rogosa, and Sharpe (MRS) media (Difco Laboratories, Franklin Lakes, NJ, USA) at $37^{\circ} \mathrm{C}$ for $18 \mathrm{~h}$. After two subcultures in MRS media, cell suspension was centrifuged at $1,500 \times \mathrm{g}, 4^{\circ} \mathrm{C}$ for $5 \mathrm{~min}$. The pellet was washed twice with sterile $0.9 \%(\mathrm{w} / \mathrm{v})$ sodium chloride solution and used for further encapsulation process.

\section{Manufacture of probiotic delivery systems}

Probiotic delivery systems were produced using the modified rennet-induced gelation of milk proteins described in Heidebach et al. [11]. Skim milk solutions (3, 5, and 10\% [w/w]) reconstituted in sterile water were adjusted to $\mathrm{pH} 5.4$ and 6.2 using $1 \mathrm{M} \mathrm{HCl}$ and cooled to $5^{\circ} \mathrm{C}$. The cell pellet was mixed with $15 \mathrm{~mL}$ of skim milk solutions with various concentration levels (3, 5 , and $10 \%[\mathrm{w} / \mathrm{w}])$ and $\mathrm{pH}(5.4$ and 6.2$)$ to obtain probiotic/skim milk mixtures with at least 9.0 $\log \mathrm{CFU} / \mathrm{mL}$ of $L$. rhamnosus $\mathrm{GG}$. Next, $51.7 \mu \mathrm{L}$ of rennet was added to $15 \mathrm{~mL}$ of probiotic/skim milk mixtures and kept at $5{ }^{\circ} \mathrm{C}$ for $60 \mathrm{~min}$. Seventy-five microliters of $1 \mathrm{M} \mathrm{CaCl}_{2}$ were added to $15 \mathrm{~mL}$ of probiotic/skim milk/rennet mixtures. The final concentration of $\mathrm{CaCl}_{2}$ in the mixture was $5 \mathrm{mM}$. To form oil-in-water (O/W) emulsions, $15 \mathrm{~mL}$ of those mixtures were added to 160 $\mathrm{g}$ of corn oil containing $5 \%(\mathrm{w} / \mathrm{w})$ span 80 and then homogenized at 8,000 rpm for 5 min using a probe-type homogenizer (Daihan scientific, Wonju, Korea). To prevent rennet-induced gelation of milk proteins, temperature was kept at $5{ }^{\circ} \mathrm{C}$ during homogenization. After the formation of $\mathrm{O} /$ W emulsions, the temperature of emulsions was controlled to $25^{\circ} \mathrm{C}$ and kept for 10 min to induce the rennet-induced gelation of milk proteins. To obtain probiotic delivery systems, $\mathrm{O} / \mathrm{W}$ emulsions were centrifuged at $15,000 \times g, 4^{\circ} \mathrm{C}$ for $1 \mathrm{~min}$ and then oils at top layer were removed. After washing 
3 times with distilled water to remove residual oils, probiotic delivery systems were collected and freeze dried.

\section{Morphological properties of probiotic delivery systems}

Formation and morphological properties of probiotic delivery systems were determined using a confocal laser scanning microscope (CLSM, Olympus FV-1000, Tokyo, Japan). To monitor probiotic delivery systems, acridine orange, a fluorescent dye, was used to stain milk proteins. Prior to the production of delivery systems, $90 \mu \mathrm{L}$ of $0.2 \%(\mathrm{w} / \mathrm{w})$ acridine orange was added to $15 \mathrm{~mL}$ of 3, 5, and 10\% (w/v) skim milk solutions and adjusted to $\mathrm{pH} 5.4$ and 6.2 with $1 \mathrm{M} \mathrm{HCl}$ followed by cooling to $5^{\circ} \mathrm{C}$. Probiotic delivery systems were manufactured according to methods described above. After freeze drying, $0.15 \mathrm{~g}$ of probiotic delivery systems were placed on a concave confocal microscope slide. The excitation and emission wavelengths were set at 488 and $526 \mathrm{~nm}$, respectively.

\section{Particle size and size distribution of probiotic delivery systems}

Particle size analyzer (1090LD shape, CILAS, Orleans, France) was used to measure the particle size (volume-mean diameter, D43) and size distribution (span value) of probiotic delivery systems. Prior to measure the size, $0.15 \mathrm{~g}$ of freeze-dried probiotic delivery systems were dispersed in 45 $\mathrm{mL}$ of $10 \%(\mathrm{w} / \mathrm{w})$ tween 80 solution followed by sonication at $50 \mathrm{~W}$ for $3 \mathrm{~min}$. Span value was calculated by following equation [21].

$$
\text { Span value }=\frac{D(0.9)-D(0.1)}{D(0.5)}
$$

where $D(0.9), D(0.1)$, and $D(0.5)$ are particle diameter at cumulative size of $90 \%, 10 \%$, and $50 \%$, respectively. A low span value indicates uniformity in size distribution.

\section{Encapsulation efficiency of probiotics}

The encapsulation efficiency of probiotics in milk-protein based delivery systems was evaluated by counting viable cells in delivery systems using a standard plate method on MRS agar. Freeze-dried probiotic delivery systems were dispersed in 10\% tween 80 solution and the number of viable cells was determined. To determine the number of viable cells in milk protein-based delivery systems, reconstituted delivery systems were enzymatically hydrolyzed using the modified method of Heidebach et al. [11]. Reconstituted delivery systems were diluted 10 times with Protease N "Amano" $(0.0024 \mathrm{~g} / 10 \mathrm{~mL})$ and kept at $40^{\circ} \mathrm{C}$ for $30 \mathrm{~min}$ with constant agitation at $150 \mathrm{rpm}$ using a shaking water bath. After reaction with Protease N "Amano", viable cells were enumerated using a standard plate method on MRS agar. Encapsulation efficiency was calculated by following equation [22].

$$
\text { Encapsulation efficiency }=\mathrm{N} / \mathrm{N}_{0} \times 100
$$

where $\mathrm{N}_{0}$ is the initial number of $L$. rbamnosus $\mathrm{GG}$ added in the preparation process and $\mathrm{N}$ is the total number of $L$. rhamnosus $\mathrm{GG}$ encapsulated in probiotic delivery systems.

\section{Viability of encapsulated probiotics under simulated gastrointestinal conditions}

The viability of encapsulated $L$. rhamnosus GG under simulated gastric and intestinal conditions was evaluated by the modified method of Chávarri et al. [23] and García-Sartal et al. [24]. To prepare simulated gastric juice (SGJ), pepsin $(0.3 \%, \mathrm{w} / \mathrm{v})$ was dissolved in $0.9 \%(\mathrm{w} / \mathrm{v}) \mathrm{NaCl}$ solution and adjusted to $\mathrm{pH}$ 2.0. Simulated intestinal juice (SIJ) was prepared with $0.65 \%(\mathrm{w} / \mathrm{v}) \mathrm{NaCl}$, 
$0.0835 \%(\mathrm{w} / \mathrm{v}) \mathrm{KCl}, 0.022 \%(\mathrm{w} / \mathrm{v}) \mathrm{NaHCO}_{3}$, and $0.3 \%(\mathrm{w} / \mathrm{v})$ bile extraction porcine and then was adjusted to $\mathrm{pH}$ 7.5. SGJ and SIJ were filtered with a $0.45 \mu \mathrm{m}$ syringe filter. Free and encapsulated probiotics (L. rhamnosus GG) were 10-fold diluted with SGJ and SIJ and then incubated at $37^{\circ} \mathrm{C}$ for $120 \mathrm{~min}$ with constant agitation at $150 \mathrm{rpm}$ using a shaking water bath (Daihan scientific). After incubation, SGJ was diluted 10 times with $0.05 \mathrm{M}$ sodium phosphate buffer $(\mathrm{pH} 7.0)$ for inactivation of pepsin. To determine the number of viable cells in milk protein-based delivery systems, delivery systems were enzymatically hydrolyzed using the modified method of Heidebach et al. [11] described earlier.

\section{Statistical analysis}

All data were expressed as a mean of three replicates. The impacts of manufacturing variables, such as skim milk concentration level and $\mathrm{pH}$, on the particle size and size distribution of probiotic delivery systems were determined by one-way analysis of variance (ANOVA) with Fisher's significant differences test with statistical significance of $p<0.05$. Repeated-measures ANOVA was used to determine the effects of manufacturing variables, incubation time, and their interactions on the survival of $L$. rhamnosus GG in simulated gastrointestinal conditions. The statistical analysis system (Version 9.1, SAS Institute, Cary, NC, USA) was used to perform ANOVA.

\section{RESULTS AND DISCUSSION}

\section{Morphological properties of probiotic delivery systems}

Modified rennet-induced gelation method [11] was used to manufacture milk protein-based probiotic delivery systems. The formation and morphological properties of probiotic delivery systems were determined using CLSM (Figs. 1 and 2). Round shaped particles with a size ranging from 100 to $200 \mu \mathrm{m}$ were observed indicating the successful development of probiotic delivery systems. An increase in the size of probiotic delivery systems was observed with an increase in the skim milk
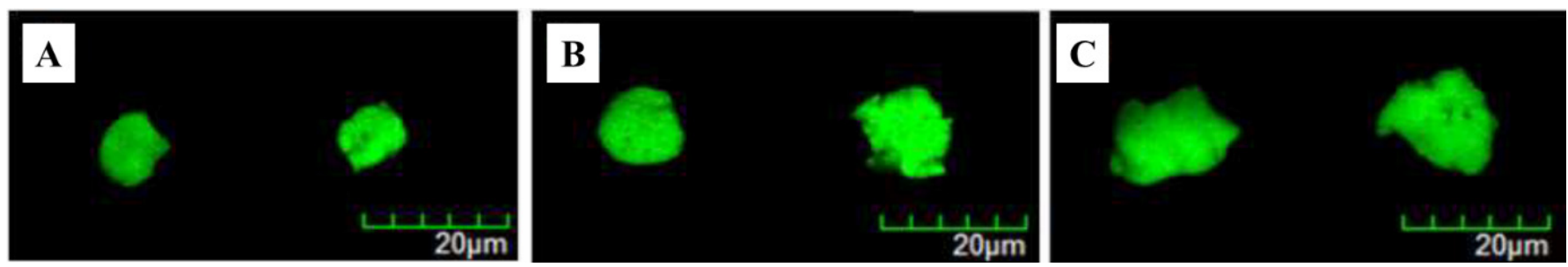

Fig. 1. Morphological properties of probiotic delivery systems prepared with various skim milk powder concentration level. Probiotic delivery systems were manufactured with $3(\mathrm{~A}), 5(\mathrm{~B})$, and $10 \%(\mathrm{w} / \mathrm{w})(\mathrm{C})$ of skim milk powder concentration levels at pH 6.2. Scale bar $=20 \mu \mathrm{m}$.
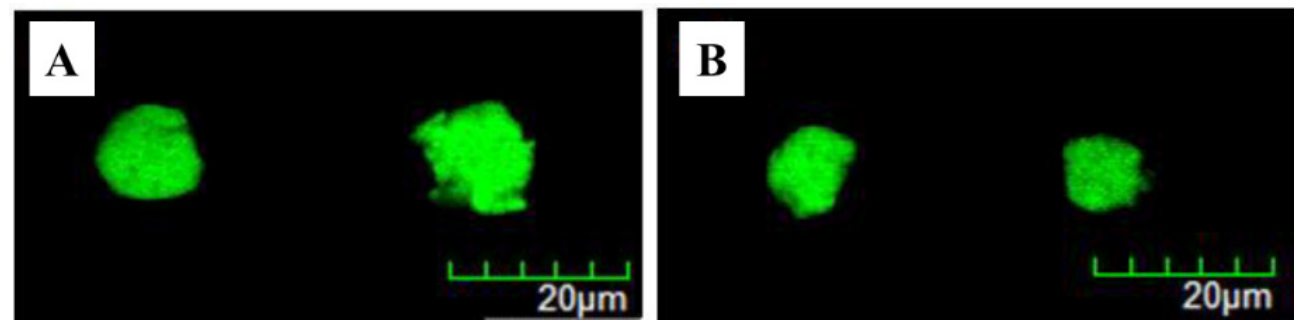

Fig. 2. Morphological properties of probiotic delivery systems prepared at various $\mathrm{pH}$. Probiotic delivery systems were manufactured $5 \%$ (w/w) of skim milk powder concentration levels at $\mathrm{pH} 6.2(\mathrm{~A})$ and $\mathrm{pH} 5.4$ (B). Scale bar $=20 \mu \mathrm{m}$. 
powder concentration level from 3 to $10 \%$ (w/w) (Fig. 1) and in $\mathrm{pH}$ from 5.4 to 6.2 (Fig. 2).

\section{Particle size and size distribution of probiotic delivery systems}

Impacts of skim milk powder concentration level and $\mathrm{pH}$ on the size of probiotic delivery systems were assessed by using particle size analyzer (Fig. 3). As skim milk powder concentration level was increased from 3 to $10 \%(\mathrm{w} / \mathrm{w})$, the size of probiotic delivery system was significantly $(p<0.05)$ increased from 27.5 to $44.4 \mu \mathrm{m}$ (Fig. 3A). The cleavage of negatively charged $\kappa$-casein molecule existed on the surface of casein micelles by rennet result in a reduction in electrostatic repulsions between casein micelles. It can lead to an increase in the aggregation of casein micelles resulting in the formation of gels [11]. Since more casein micelles as building blocks may participate in the production of probiotic delivery system at higher skim milk powder concentration level, their intermolecular associations could be increased with an increase in skim milk powder concentration level, which may lead to the formation of thicker and bigger protein network. This may result in an increase in the size of milk protein-based probiotic delivery systems.

A decrease in $\mathrm{pH}$ from 6.2 to 5.4 resulted in a significant $(p<0.05)$ decrease in the size of probiotic delivery systems (Fig. 3B). Because the isoelectric $\mathrm{pH}$ of casein micelles is $\sim 4.6$, a decrease in $\mathrm{pH}$ from 6.2 to 5.4 lead to a decrease in the net negative charges of casein micelle and therefore hydrophobic interactions between casein micelles could be increased [11,17]. An increase in the hydrophobic interactions between casein micelles may lead to an increase in the intramolecular associations of protein gel network, which may result in the shrinkage of gel network and formation of more compact and small particles at $\mathrm{pH} 5.4$ [11,25].

The size distribution of probiotic delivery systems was shown in Fig. 4. Span value is a statistical parameter that can be useful to evaluate the distribution of particle size. Smaller the span value indicates narrower size distribution (homogeneous) [21,26]. In all conditions, span values of probiotic delivery systems were ranged from 1.5 to 3.0 indicating that probiotic delivery systems had narrow size distribution and formation of homogeneous particles [27].

\section{Encapsulation efficiency of probiotics}

Fig. 5 shows the effects of skim milk powder concentration level and $\mathrm{pH}$ on the encapsulation efficiency of probiotics. An increase in the skim milk powder concentration level from 3 to 10\% $(w / w)$ resulted in a significant $(p<0.05)$ increase in the encapsulation efficiency of probiotics from $76.0 \%$ to $88.5 \%$ (Fig. $5 \mathrm{~A}$ ). An increase in skim milk powder concentration level may lead

A

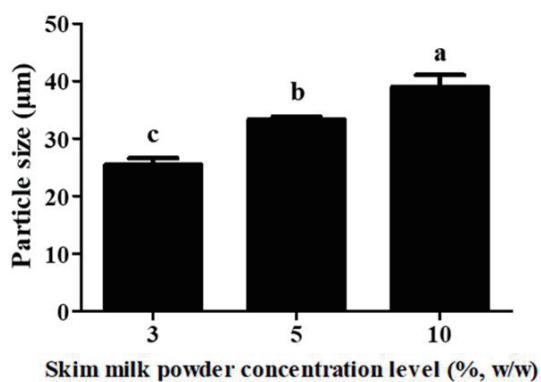

B

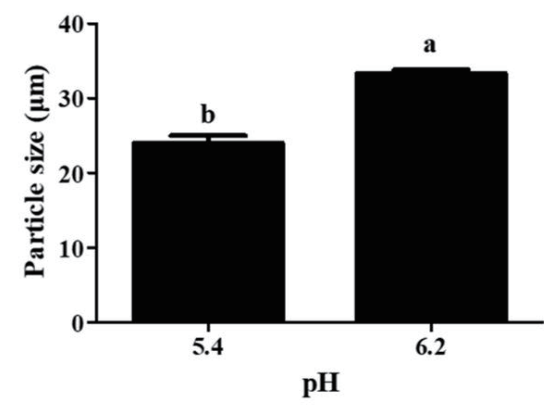

Fig. 3. Impacts of skim milk powder concentration level and $\mathrm{pH}$ on the size of probiotic delivery systems. (A) Probiotic delivery systems were manufactured with 3, 5, and $10 \%(\mathrm{w} / \mathrm{w})$ skim milk powder concentration levels at $\mathrm{pH}$ 6.2. (B) Probiotic delivery systems were manufactured with $5 \%(\mathrm{w} / \mathrm{w})$ skim milk powder concentration levels at pH 5.4 and 6.2. Different letters on a column indicate significant $(p<0.05)$ differences. 
A

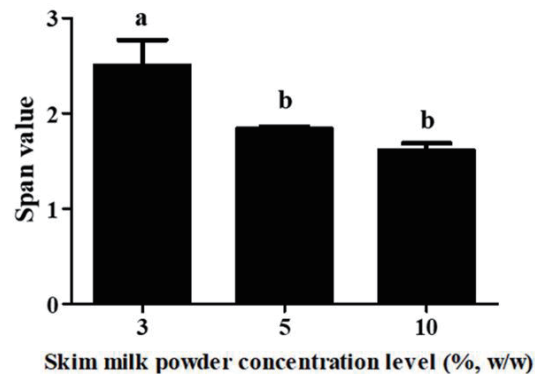

B

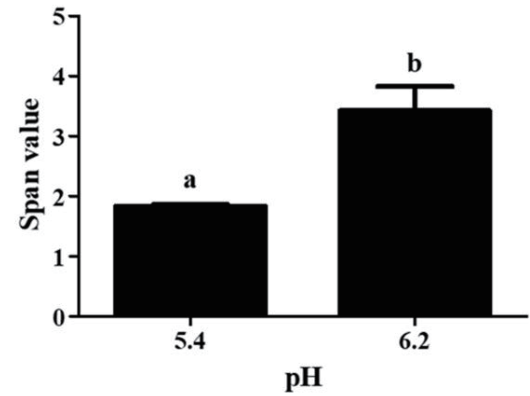

Fig. 4. Effects of skim milk powder concentration level and pH on the span value of probiotic delivery systems. (A) Probiotic delivery systems were manufactured with 3, 5, and $10 \%(\mathrm{w} / \mathrm{w})$ skim milk powder concentration levels at $\mathrm{pH}$ 6.2. (B) Probiotic delivery systems were manufactured with $5 \%(\mathrm{w} / \mathrm{w})$ skim milk powder concentration levels at pH 5.4 and 6.2. Different letters on a column indicate significant $(p<0.05)$ differences.

A

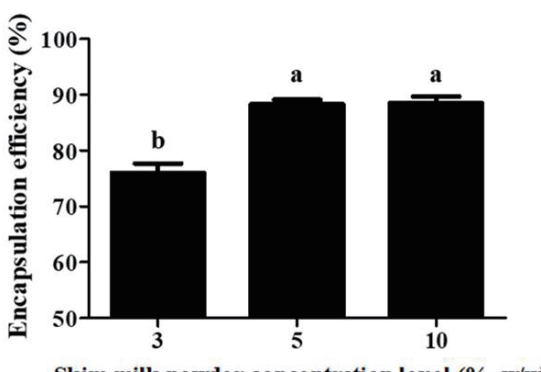

B

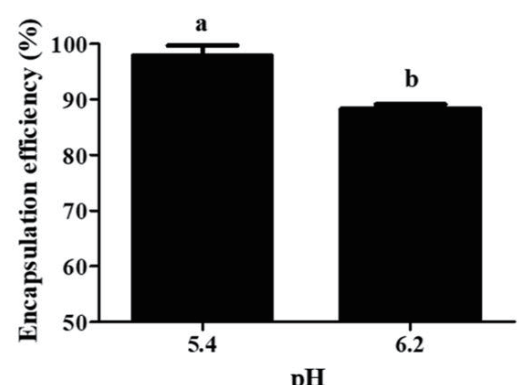

pH

Fig. 5. Impacts of skim milk powder concentration level and pH on the encapsulation efficiency of probiotics. (A) Probiotic delivery systems were manufactured with 3,5 , and $10 \%(\mathrm{w} / \mathrm{w})$ skim milk powder concentration levels at $\mathrm{pH}$ 6.2. (B) Probiotic delivery systems were manufactured with $5 \%(\mathrm{w} / \mathrm{w})$ skim milk powder concentration levels at pH 5.4 and 6.2. Different letters on a column indicate significant $(p<0.05)$ differences.

to the formation of bigger and thicker milk protein-based delivery systems (Fig. 3A). Therefore, it could provide more effective barriers to encapsulated probiotics resulting in an increase in the encapsulation efficiency of probiotics. Similar results were reported by Sheu et al. [18] and Lee and Heo [28]. They reported that more probiotics were encapsulated in bigger delivery systems.

Although the particle size of probiotic delivery systems was decreased as $\mathrm{pH}$ was decreased from 6.2 to 5.4 , encapsulation efficiency of probiotics was significantly $(p<0.05)$ increased from 88.3 to $97.8 \%$ with a decrease in $\mathrm{pH}$ (Fig. $5 \mathrm{~B})$. Because same protein concentration level $(5 \%, \mathrm{w} / \mathrm{w})$ was used to manufacture those probiotic delivery systems at different $\mathrm{pH}$, an increase in encapsulation efficiency may be due to increased intramolecular associations between protein molecules in rennet-induced milk protein gel networks. It is known that chymosin has the optimum $\mathrm{pH}$ for the hydrolysis of $\kappa$-casein, which is 5.1-5.3 [29,30]. Imafidon and Farkye [31] also reported that the $\kappa$-casein cleavage by chymosin was greatest at $\mathrm{pH}$ 5.3-5.6. These results indicate that a decrease in $\mathrm{pH}$ from 6.2 to 5.4 could lead to an increase in the activity of chymosin on the hydrolysis of $\kappa$-casein. Since an increase in the hydrolysis of $\kappa$-casein could contribute to a decrease in electrostatic repulsions and an increase in hydrophobic attractions between casein micelles, more compact and denser protein networks could be formed at lower $\mathrm{pH}$ resulting in an increase in the encapsulation efficiency of probiotics [11,32,33]. 


\section{Viability of probiotics in simulated gastrointestinal conditions}

Impacts of encapsulation in milk protein-based delivery systems on the viability of probiotic stain, L. rbamnosus GG, during incubation under gastrointestinal conditions were presented in Table 1. Repeated measures ANOVA exhibited that encapsulation in milk protein-based delivery system (treat, $p<0.0001$ ), incubation time (time, $p=0.0005)$, and their interaction $(p<0.0001)$ in SGJ had a significant effect on the viability of $L$. rbamnosus GG (Table 1 ). The number of viable cells was decreased during incubation in SGJ. A decrease in the viability of probiotics can be attributed to the high acidity of gastric juice under gastric conditions. When L. rhamnosus GG was encapsulated in milk protein-based delivery system, overall mean viable cell number was significantly $(p=0.0005)$ increased from 7.35 to $7.88 \mathrm{CFU} / \mathrm{mL}$. It implies that encapsulation in milk protein-based delivery system is a useful method to enhance the viability of $L$. rhamnosus $G G$ in gastric condition. When free and encapsulated L. rhamnosus GG were exposed to SIJ, the repeated measures ANOVA results presented that encapsulation (treat, $p=0.0934$ ), incubation time (time, $p=0.8153$ ), and their interaction $(p=0.7306)$ were not significant indicating that bile salts and intestinal $\mathrm{pH}$ did not affect the viability of $L$. rhamnosus $\mathrm{GG}$ was not affected under intestinal juice condition, such as bile

Table 1. Effects of probiotic encapsulation in milk protein-based delivery systems on the viability of probiotics during incubation in simulated gastric juice and simulated intestinal juice ${ }^{1)}$

\begin{tabular}{lrc}
\hline \multicolumn{1}{c}{ Time $(\mathrm{min})$} & Free probiotic & Encapsulated $^{\text {probiotic }}{ }^{2}$ \\
\hline SGJ & & \\
0 & 8.97 & 8.91 \\
30 & 7.92 & 8.01 \\
60 & 6.70 & 7.63 \\
120 & 5.82 & 6.98 \\
Overall $(0-120)^{3)}$ & 7.35 & 7.88 \\
Pooled SD & 0.11 & \\
$p$-value & & \\
Treat ${ }^{4)}$ & 0.0005 & \\
Time ${ }^{5)}$ & $<0.0001$ & \\
Treat $\times$ Time ${ }^{6)}$ & $<0.0001$ & \\
SIJ & & 8.91 \\
0 & 8.97 & 8.94 \\
30 & 8.87 & 8.92 \\
60 & 8.84 & 8.91 \\
120 & 9.02 & 8.92 \\
Overall $(0-120)$ & 8.93 & \\
Pooled SD & 0.15 & \\
$p$-value & & \\
Treat & 0.9034 & \\
Time & 0.8153 & \\
Treat $\times$ Time & 0.7306 & \\
\hline
\end{tabular}

${ }^{11}$ Data are mean values of triplicates and are expressed as $\mathrm{Log}_{10} \mathrm{CFU} / \mathrm{mL}$.

${ }^{2}$ Probiotics (Lactobacillus rhamnosus GG) were encapsulated in milk protein-based delivery system prepared with $5 \%$ (w/w) skim milk powder at $\mathrm{pH} 6.2$.

${ }^{3}$ Mean values of overall incubation period.

${ }^{4}$ Probiotic encapsulation in milk protein-based delivery systems.

${ }^{5}$ Incubation time in minutes.

${ }^{6}$ Interaction between treat and time.

SGJ, simulated gastric juice; SIJ, simulated intestinal juice. 
salts and intestinal $\mathrm{pH}$.

Table 2 shows the impacts of manufacturing variables, such as skim milk powder concentration level and $\mathrm{pH}$ on the viability of encapsulated probiotics, L. rhamnosus GG, in simulated gastrointestinal conditions. Repeated measures ANOVA revealed significant effects on the skim milk powder concentration level (treat, $p=0.0001)$, incubation time $(p<0.0001)$, and their interaction $(p<0.0001)$ on the viability of $L$. rbamnosus GG in SGJ while no significant effects were observed in SIJ (Table 2). As skim milk powder concentration level was increased from 3 to $10 \%(\mathrm{w} / \mathrm{w})$, the overall viability of L. rhamnosus GG in SGJ was increased from 7.34 to 7.69 $\mathrm{CFU} / \mathrm{mL}$ indicating that skim milk powder concentration level can be a key factor to enhance the viability of probiotics in gastric condition. An increase in protein content by increasing skim milk powder concentration level may enhance the intermolecular associations between casein micelles resulting in the production of thicker protein networks. Those thicker protein gel networks could

Table 2. Impacts of skim milk powder concentration level and pH on the viability of encapsulated probiotics during incubation in simulated gastric juice and simulated intestinal juice ${ }^{1)}$

\begin{tabular}{|c|c|c|c|c|c|}
\hline \multirow{2}{*}{ Time (min) } & \multicolumn{3}{|c|}{ Skim milk powder concentration level $(\%[w / w])^{2)}$} & \multicolumn{2}{|c|}{$\mathrm{pH}^{3)}$} \\
\hline & 3 & 5 & 10 & 5.4 & 6.2 \\
\hline \multicolumn{6}{|l|}{ SGJ } \\
\hline 0 & 8.94 & 8.91 & 9.00 & 8.96 & 8.91 \\
\hline 30 & 7.81 & 8.01 & 8.01 & 8.72 & 8.01 \\
\hline 60 & 6.57 & 7.63 & 6.84 & 7.96 & 7.63 \\
\hline 120 & 6.04 & 6.98 & 6.92 & 7.70 & 6.98 \\
\hline Overall $(0-120)^{4)}$ & 7.34 & 7.88 & 7.69 & 8.33 & 7.88 \\
\hline Pooled SD & 0.11 & & & 0.09 & \\
\hline \multicolumn{6}{|l|}{$p$-value } \\
\hline Treat $^{5)}$ & 0.0001 & & & $<0.0001$ & \\
\hline Time $^{6)}$ & $<0.0001$ & & & $<0.0001$ & \\
\hline Treat $\times$ Time $^{7}$ & $<0.0001$ & & & 0.0003 & \\
\hline \multicolumn{6}{|l|}{ SIJ } \\
\hline 0 & 8.94 & 8.91 & 9.00 & 8.96 & 8.91 \\
\hline 30 & 8.87 & 8.94 & 8.94 & 8.72 & 8.94 \\
\hline 60 & 9.07 & 8.92 & 9.01 & 7.96 & 8.92 \\
\hline 120 & 8.92 & 8.91 & 9.00 & 7.70 & 8.91 \\
\hline Overall $(0-120)$ & 8.95 & 8.92 & 8.99 & 8.33 & 8.92 \\
\hline Pooled SD & 0.11 & & & 0.10 & \\
\hline \multicolumn{6}{|l|}{$p$-value } \\
\hline Treat & 0.2581 & & & 0.3575 & \\
\hline Time & 0.6490 & & & 0.8375 & \\
\hline Treat $\times$ Time & 0.8613 & & & 0.8949 & \\
\hline
\end{tabular}

${ }^{1)}$ Data are mean values of triplicates and are expressed as $\log _{10} \mathrm{CFU} / \mathrm{mL}$.

${ }^{2)}$ Probiotics (Lactobacillus rhamnosus GG) were encapsulated in milk protein-based delivery system prepared with various skim milk powder concentration levels $(3,5$, and $10 \%[\mathrm{w} / \mathrm{w}])$ at $\mathrm{pH} 6.2$.

${ }^{3)}$ Probiotics (L. rhamnosus GG) were encapsulated in milk protein-based delivery system prepared with skim milk powder concentration level of $5 \%(\mathrm{w} / \mathrm{w})$ at various $\mathrm{pH}$ (5.4 and 6.2).

${ }^{4)}$ Mean values of overall incubation period.

${ }^{5}$ Probiotic encapsulation in milk protein-based delivery systems.

${ }^{6)}$ Incubation time in minutes.

${ }^{7)}$ Interaction between treat and time.

SGJ, simulated gastric juice; SIJ, simulated intestinal juice. 
reduce the diffusion of gastric juice with very high acidity into the probiotic delivery systems [34]. Therefore, delivery systems prepared with higher milk protein concentration level can provide better protections for probiotics in harsh gastric conditions compared with delivery systems treated with lower milk protein concentration level. Similar results were reported by Shi et al. [34] who presented that probiotic delivery systems produced with higher milk concentration could provide better protections for L. bulgaricus in SGJ.

In repeated measures ANOVA, a significant effect of $\mathrm{pH}$ (treat, $p<0.0001$ ), incubation time $(p<0.0001)$, and their interaction ( $p=0.0003)$ on the viability of of L. rhamnosus GG in SGJ was observed while there were no significant effects observed in SIJ (Table 2). Overall viability of $L$. rhamnosus $\mathrm{GG}$ in SGJ was increased from 7.88 to $8.33 \mathrm{CFU} / \mathrm{mL}$ as $\mathrm{pH}$ was decreased from 6.2 to 5.4. As we described earlier, a decrease in $\mathrm{pH} 6.2$ to 5.4 may enhance hydrophobic attractions between casein micelles forming more compact and denser protein gel networks. The production of denser protein gel networks could reduce acid diffusions into milk protein-based delivery systems in SGJ, which may contribute to higher viability of $L$. rbamnosus encapsulated in milk protein-based delivery system prepared at $\mathrm{pH}$ 5.4.

In conclusion, probiotic strain, $L$. rhamnosus $\mathrm{GG}$, was successfully encapsulated in milk proteinbased delivery systems using a modified rennet-induced gelation method. Skim milk powder concentration level and $\mathrm{pH}$ were major manufacturing variables affecting the physicochemical properties of milk protein-based probiotic delivery systems, such as a particle size, size distribution, encapsulation efficiency, and viability of probiotics in simulated gastrointestinal tract. It can be attributed to intra- and intermolecular associations between milk protein molecules during rennetinduced gelation. Milk protein-based delivery systems can be used for enhancing the viability of probiotics and these food-grade probiotic delivery systems can be useful to apply probiotics to various foods.

\section{REFERENCES}

1. FAO [Food and Agriculture Organization of the United Nations], WHO [World Health Organization]. Health and nutritional properties of probiotics in food including powder milk with live lactic acid bacteria. Rome: FAO; 2006. FAO. Food and Nutrition Paper No.: 85.

2. Rowland IR, Capurso L, Collins K, Cummings J, Delzenne N, Goulet O, et al. Current level of consensus on probiotic science-report of an expert meeting-London, 23 November 2009. Gut Microbes. 2010;1:436-9. https://doi.org/10.4161/gmic.1.6.13610

3. Zhao M, Huang X, Zhang H, Zhang Y, Gänzle M, Yang N, et al. Probiotic encapsulation in water-in-water emulsion via heteroprotein complex coacervation of type-A gelatin/sodium caseinate. Food Hydrocolloids. 2020;105:105790. https://doi.org/10.1016/j.foodhyd.2020.105790

4. Anal AK, Singh H. Recent advances in microencapsulation of probiotics for industrial applications and targeted delivery. Trends Food Sci Technol. 2007;18:240-51. https://doi.org/10.1016/ j.tifs.2007.01.004

5. Burgain J, Gaiani C, Linder M, Scher J. Encapsulation of probiotic living cells: from laboratory scale to industrial applications. J Food Eng. 2011;104:467-83. https://doi.org/10.1016/j.jfoodeng.2010.12.031

6. Patel AR. Probiotic fruit and vegetable juices-recent advances and future perspective. Int Food Res J. 2017;24:1850-7.

7. Librán CM, Castro S, Lagaron JM. Encapsulation by electrospray coating atomization of probiotic strains. Innov Food Sci Emerg Technol. 2017;39:216-22. https://doi.org/10.1016/ j.ifset.2016.12.013 
8. FAO [Food and Agriculture Organization of the United Nations], WHO [World Health Organization]. CODEX Standard for fermented milks. Rome: FAO; 2018. Report No.: CXS 243-2003.

9. Champagne CP, Gardner NJ, Roy D. Challenges in the addition of probiotic cultures to foods. Crit Rev Food Sci Nutr. 2005;45:61-84. https://doi.org/10.1080/10408690590900144

10. Ranadheera CS, Vidanarachchi JK, Rocha RS, Cruz AG, Ajlouni S. Probiotic delivery through fermentation: dairy vs. non-dairy beverages. Fermentation. 2017;3:67. https://doi.org/10.3390/ fermentation 3040067

11. Heidebach T, Först P, Kulozik U. Microencapsulation of probiotic cells by means of rennet-gelation of milk proteins. Food Hydrocoll. 2009;23:1670-7. https://doi.org/10.1016/j.foodhyd.2009.01.006

12. Burgain J, Gaiani C, Cailliez-Grimal C, Jeandel C, Scher J. Encapsulation of Lactobacillus rhamnosus GG in microparticles: influence of casein to whey protein ratio on bacterial survival during digestion. Innovative Food Sci Emerging Technol. 2013;19:233-42. https://doi. org/10.1016/j.ifset.2013.04.012

13. Maciel GM, Chaves KS, Grosso CRF, Gigante ML. Microencapsulation of Lactobacillus acidophilus La- 5 by spray-drying using sweet whey and skim milk as encapsulating materials. J Dairy Sci. 2014;97:1991-8. https://doi.org/10.3168/jds.2013-7463

14. Yonekura L, Sun H, Soukoulis C, Fisk I. Microencapsulation of Lactobacillus acidophilus NCIMB 701748 in matrices containing soluble fibre by spray drying: technological characterization, storage stability and survival after in vitro digestion. J Funct Foods. 2014;6:205-14. https://doi.org/10.1016/j.jff.2013.10.008

15. Ranadheera CS, Evans CA, Adams MC, Baines SK. Microencapsulation of Lactobacillus acidophilus LA-5, Bifidobacterium animalis subsp. lactis BB-12 and Propionibacterium jensenii 702 by spray drying in goat's milk. Small Ruminant Res. 2015;123:155-9. https://doi. org/10.1016/j.smallrumres.2014.10.012

16. Picot A, Lacroix C. Encapsulation of bifidobacteria in whey protein-based microcapsules and survival in simulated gastrointestinal conditions and in yoghurt. Int Dairy J. 2004;14:505-15. https://doi.org/10.1016/j.idairyj.2003.10.008

17. Horne DS, Lucey JA. Rennet-induced coagulation of milk. In: Fox PF, McSweeney PLH, Cogan TM, Guinee TP, editors. Cheese: chemistry, physics and microbiology. London: Academic Press; 2017.p. 115-43.

18. Sheu TY, Marshall RT, Heymann H. Improving survival of culture bacteria in frozen desserts by microentrapment. J Dairy Sci. 1993;76:1902-7. https://doi.org/10.3168/jds.S00220302(93)77523-2

19. Chandramouli V, Kailasapathy K, Peiris P, Jones M. An improved method of microencapsulation and its evaluation to protect Lactobacillus spp. in simulated gastric conditions. J Microbiol Methods. 2004;56:27-35.https://doi.org/10.1016/j.mimet.2003.09.002

20. Ha HK, Rankin SA, Lee MR, Lee WJ. Development and characterization of whey protein-based nano-delivery systems: a review. Molecules. 2019;24:3254. https://doi.org/ 10.3390/ molecules24183254

21. Chew NYK, Chan HK. Effect of powder polydispersity on aerosol generation.J Pharm Pharm Sci. 2002;5:162-8.

22. Abbaszadeh S, Gandomi H, Misaghi A, Bokaei S, Noori N. The effect of alginate and chitosan concentrations on some properties of chitosan-coated alginate beads and survivability of encapsulated Lactobacillus rhamnosus in simulated gastrointestinal conditions and during heat processing.J Sci Food Agric. 2014;94:2210-6. https://doi.org/10.1002/jsfa.6541 
23. Chávarri M, Marañón I, Ares R, Ibáñez FC, Marzo F, Villarán MC. Microencapsulation of a probiotic and prebiotic in alginate-chitosan capsules improves survival in simulated gastro-intestinal conditions. Int J Food Microbiol. 2010;142:185-9. https://doi.org/10.1016/j.ijfoodmicro.2010.06.022

24. García-Sartal C, Romarís-Hortas V, Barciela-Alonso MC, Moreda-Piñeiro A, Dominguez-Gonzalez R, Bermejo-Barrera P. Use of an in vitro digestion method to evaluate the bioaccessibility of arsenic in edible seaweed by inductively coupled plasma-mass spectrometry. Microchem J.2011;98:91-6. https://doi.org/10.1016/j.microc.2010.12.001

25. Marshall RJ. An improved method for measurement of the syneresis of curd formed by rennet action on milk.J Dairy Res. 1982;49:329-36. https://doi.org/10.1017/S0022029900022433

26. Vladisavljević GT, Tesch S, Schubert H. Preparation of water-in-oil emulsions using microporous polypropylene hollow fibers: influence of some operating parameters on droplet size distribution. Chem Eng Process Process Intensif. 2002;41:231-8. https://doi.org/10.1016/S02552701(01)00138-6

27. Gallotti F, Lavelli V, Turchiuli C. Application of Pleurotus ostreatus $\beta$-glucans for oil-inwater emulsions encapsulation in powder. Food Hydrocolloids. 2020;105:105841. https://doi. org/10.1016/j.foodhyd.2020.105841

28. Lee KY, Heo TR. Survival of Bifidobacterium longum immobilized in calcium alginate beads in simulated gastric juices and bile salt solution. Appl Environ Microbiol. 2000;66:869-73. https://doi.org/10.1128/AEM.66.2.869-873.2000

29. Fox PF. Influence of temperature and $\mathrm{pH}$ on the proteolytic activity of rennet extract. J Dairy Sci. 1969;52:1214-8. https://doi.org/10.3168/jds.S0022-0302(69)86727-5

30. Shalabi SI, Fox PF. Influence of $\mathrm{pH}$ on the rennet coagulation of milk. J Dairy Res. 1982;49:153-7. https://doi.org/10.1017/S0022029900022238

31. Imafidon GI, Farkye NY. Influence of $\mathrm{pH}$ on chymosin action in solutions of different $\kappa$-casein variants.J Agric Food Chem. 1994;42:1598-601. https://doi.org/10.1021/jf00044a002

32. Nájera AI, Renobales M, Barron LJR. Effects of $\mathrm{pH}$, temperature, $\mathrm{CaCl} 2$ and enzyme concentrations on the rennet-clotting properties of milk: a multifactorial study. Food Chem. 2003;80:345-52. https://doi.org/10.1016/S0308-8146(02)00270-4

33. Hill AR, Kethireddipalli P. Dairy products: cheese and yogurt. In: Eskin NAM, Shahidi F, editors. Biochemistry of foods. Amsterdam: Elsevier; 2013. p. 319-62.

34. Shi LE, Li ZH, Li DT, Xu M, Chen HY, Zhang ZL, et al. Encapsulation of probiotic Lactobacillus bulgaricus in alginate-milk microspheres and evaluation of the survival in simulated gastrointestinal conditions. J Food Eng. 2013;117:99-104. https://doi.org/10.1016/j.jfoodeng.2013.02.012 